\title{
The Antecedent of Employee Performance and the Impact of Job Satisfaction on PT. Bank BNI in the Working Area of Bank Indonesia Lhokseumawe
}

\author{
Marbawi*, Likdanawati, Hamdiah and Yulius Dharma \\ Department Management, Faculty of Economic and Business, Universitas Malikussaleh, \\ Aceh, Indonesia
}

\section{"Email:marbawi@unimal.ac.id}

\begin{abstract}
This study was conducted with the aim to determine the empirical evidence of the antecedent of employee's performance and influence toward employee job satisfaction in the working area of Bank Indonesia Lhokseumawe. The population used in this study were 127 respondents, while the sample was 127 respondents in Bank BNI in the working area of Bank Indonesia Lhokseumawe. The sampling of this study was taken using a census sampling technique. Hypothesis testing was conducted by structural equation modeling and data were analyzed with the help of AMOS. The result of hypothesis test shows that organizational culture and leadership style significantly influenced the work performance, but work motivation is not influenced to the job satisfaction, otherwise, the organization culture, work motivation and leadership style significantly influenced the job satisfaction of bank BNI in the working area of Bank Indonesia of Lhokseumawe.
\end{abstract}

Keywords: Organization Culture, Work Motivation, Leadership Style, Job Satisfaction, Employee Performace

\section{INTRODUCTION}

PT. Bank BNI is state-owned commercial banks of Indonesia Government, which is committed strengthen themselves as a leading bank in Indonesia with business activities raised funds (funding), giving credit to the community (lending) and provide financial service (services), here is the role of Bank BNI as a financial intermediary (financial intermediary) also serves as a trust institution (agent of trust) as the construction of economic (agents of development) and the community service (agent of services), who is participated in developing economic of Aceh.

PT. Bank Negara Indonesia (Persero) Tbk is one of the biggest banks in Indonesia. It is established since 1946, along with the development of the banking business that continues to increase, competition has become tighter and BNI is required to be able to compete, especially with its closest competitors, based on data obtained from Bank Indonesia there are four major banks that are BNI's main competitors, namely Bank Mandiri, BRI, BCA and CIMB Niaga based on assets, third party funds, and annual profits.

\section{OBJECTIVES AND BENEFITS OF STUDY}

1. The Aims of the Study

Based on the problems exist above, the objectives of this study are:

a. To review and analyze the influence of the cultural organization on the performance of an employee PT. BNI Lhokseumawe in the working area of Bank Indonesia. 
b. To review and analyze the influence of leadership style toward the employee performance of PT.BNI Lhokseumawe in the working area of Bank Indonesia.

c. To know and to analyze the influence of work motivation on the performance of employees at PT. BNI in the working area of Bank Indonesia Lhokseumawe.

d. To review and analyze the influence of cultural organization of work satisfaction at PT. BNI in the working area of Bank Indonesia Lhokseumawe.

e. To review and analyze the influence of the work on the performance of an employee at PT. BNI in the working area of Bank Indonesia Lhokseumawe.

f. To review and analyze the leadership of satisfaction work an employee at PT. BNI in the working area of Bank Indonesia Lhokseumawe.

g. To review and analyze the influence of work satisfaction on employee performance against an employee at PT. BNI in the working area of Bank Indonesia Lhokseumawe.

\section{LITERATURE REVIEW}

\section{Theory of Organizational Behaviour}

According to Mas'ud (2004),

Organizational behavior is a system of meaning, values, and beliefs shared by an organization that is a reference for action and distinguishes one organization from another organization. While explained that Robbins (2013) Organizational culture refers to a system of shared meanings together were shared by members that distinguishes the organization from other organizations.

\section{Theory of Work Motivations}

Robbins (2013) said that motivation is a willingness to spend a high level of effort on organizational goals which is conditioned by the ability of the effort to meet some individual needs. A need is an internal condition that causes certain results to look attractive. Besides, Luthans (2011) added motivation is a process that is started with physiological or psychological deficiencies that drive behaviors or impulses aimed at goals or incentives.

\section{Theory of leadership style}

Rivai (2014) said that leadership is the process of influencing the activities of individuals or groups in an effort to achieve goals in certain situations. Leadership style basically contains an understanding as an embodiment of the behavior of a leader, which involves the ability to lead. This embodiment usually forms a certain pattern or form. This understanding of leadership style is in accordance with the opinion expressed by Luthan (2011) is someone who can influence other people or groups to perform the maximum performance that has been set in accordance with organizational goals.

\section{Theory of Satisfaction Work}

The definition of job satisfaction stated by Luthans (2011) is a happy emotional state or someone positive or pleasant emotion resulting from the assessment of a job or work experience. According to Robbins (2013), job satisfaction as a positive feeling about one's work is the result of an evaluation of its characteristics. Job satisfaction someone can feel whether his work is fun or not pleasant to do (Bangun, 2012).

\section{Theory of Employees Performance}

Bernadin \& Russell (1998) set limits on performance as "the record of outcomes produced in a specified job function or activity during, a specified time period" (note the outcome that results from the function of a particular job or activity during a certain time period. Based on Bangun (2012) performance is the result of work achieved by someone based on the requirements of the job requirements. A job has certain requirements to be done in achieving goals which are also referred to as work standards (job standards), so the job standards are high which is expected to be a certain job to be 
completed properly by employees in all organizations.

\section{Conceptual Framework}

According to Sekaran (2015), the framework of thinking is the rationale of research that is synthesized from facts, observations and research studies. The framework includes theories, propositions or concepts that will be the basis of research. The relationship between the variables used in this study can be seen in Figure 1 below:

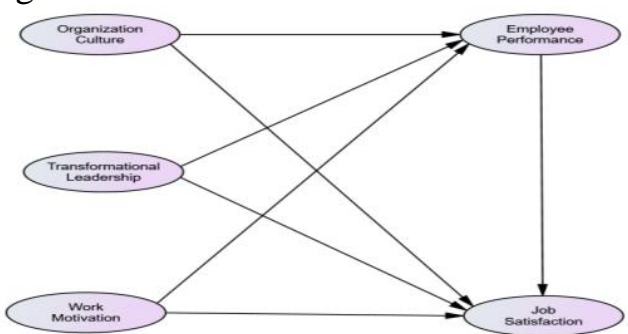

Source: Siahaan (2017), Marbawi (2018) dan Lumbanraja, (2008)

Figure 1. Conceptual framework

\section{Research Hypothesis}

The hypothesis is an idea to look for facts that must be collected. Hypothesis is a temporary question or the most probable allegation that still needs to be sought. Based on the above framework and research conducted by several previous researchers, a hypothesis can be prepared as follows:

$\mathrm{H}_{1}=$ There is an influence of organizational culture on employee performance in PT BNI in the work area of Bank Indonesia Lhokseumawe.

$\mathrm{H}_{2}=$ There is an influence of leadership style on employee performance in PT BNI in the work area of Bank Indonesia Lhokseumawe.

$\mathrm{H}_{3}=$ There is an influence of work motivation on employee performance in PT BNI in the work area of Bank Indonesia Lhokseumawe.

$\mathrm{H}_{4}=$ There is an influence of organizational culture on work satisfaction of employee performance in PT BNI in the work area of Bank Indonesia Lhokseumawe

$\mathrm{H}_{5}=$ There is an influence of work motivation on work satisfaction of employee performance in PT BNI in the work area of Bank Indonesia Lhokseumawe

$\mathrm{H}_{6}=$ There is an influence of leadership style on work satisfaction of employee performance in PT BNI in the work area of Bank Indonesia Lhokseumawe

$\mathrm{H}_{7}=$ There is an influence of employee performance in work satisfaction in PT BNI in the work area of Bank Indonesia Lhokseumawe

\section{RESEARCH METHODS}

\section{Location}

The location of this research is in PT. BNI Branch Office in the working area of Bank Indonesia Lhokseumawe. As for the objects in this study were all employees in the offices of Bank BNI Branch of Lhokseumawe, Bireuen, and Langsa.

\section{Population and Sample}

According to Ferdinand (2014) "Population is a combination of all elements in the form of events, things or people who have similar characteristics that are the center of attention of a researcher because it is seen as a universe of research. So the population in this study is all employees of Bank BNI branch offices in the working area of Bank Indonesia as many as 127 employees.

The sample is a subset of the population, consisting of several members of the population. In this study, the sampling technique was carried out by the census method. The implementation was carried out by means of all employee populations being sampled, so the sample in this study was 127 employees of Bank BNI branch offices in the working area of Bank Indonesia. 


\section{Technique of Data Collection}

Based on the type of data needed, then the data collection technique used in this study is to use a questionnaire. A questionnaire is a tool in the form of a series of questions submitted in writing submitted to subjects to get answers in writing from Bank BNI employees about the analysis of organizational culture, motivation work, and leadership style and on the performance of employees of Bank $\mathrm{BNI}$ in working areas of Bank Indonesia branch of Lhokseumawe.

\section{Technique of Data Analysis}

Inferential statistics are a method related to the sample analysis for drawing conclusions about population characteristics. After collecting data and information in the field, then to manage the data and information. The authors use the method of the Structural Equation Model (SEM) in the model and hypothesis testing, SEM or structural equation models are a set of statistical techniques that allow testing a series of relative relationships complicated, cumulatively (Ghozali, 2014). In this study two types of analytical techniques are used, namely:

1. Confirmatory factor analysis in SEM is used to confirm the most dominant factors in a group of variables.

2. Regression Weight in SEM is used to examine how much influence between the variables.

\section{RESULT AND DISCUSSION Result Analysis}

Based on the results of data analysis that has been collected on 127 respondents, a structural analysis (SEM) will be presented, as follows:

\section{Confirmatory Factor Analysis Construct Eksogen}

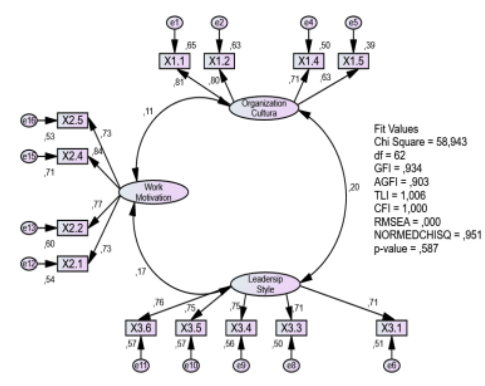

Figure: 2 CFA Construct Eksogen

Table 1 : Factor Loading CFA Kontruk

\begin{tabular}{|c|c|c|c|c|c|}
\hline \multicolumn{6}{|c|}{ Eksogen } \\
\hline \multicolumn{3}{|c|}{ Regression Weights } & Estimate & Cut Off & Kesinupulan \\
\hline $\mathrm{X} 1.1$ & $<\ldots$ & Organization_Cultura &, 808 & $>0,60$ & Valid \\
\hline $\mathrm{X} 1.2$ & $<-$ & Organization Cultura &, 795 & $>0,60$ & Valid \\
\hline X1.4 & $<--$ & Organization_Cultura & ,709 & $>0,60$ & Valid \\
\hline $\mathrm{X} 1.5$ & $<--$ & Organization_Cultura &, 625 & $>0,60$ & Valid \\
\hline $\mathrm{X} 2.1$ & $<\ldots$ & Work_Motivation &, 733 & $>0,60$ & Valid \\
\hline $\mathrm{X} 2.2$ & $<-$ & Work_Motivation &, 772 & $>0,60$ & Valid \\
\hline X2.4 & $<-$ & Work_Motivation & 841 & $>0,60$ & Valid \\
\hline $\mathrm{X} 2.5$ & $<-$ & Work_Motivation &, 726 & $>0,60$ & Valid \\
\hline X3.1 & $<-$ & Leadersip_Style &, 711 & $>0,60$ & Valid \\
\hline $\mathrm{X} 3.3$ & $<\ldots$ & Leadersip_Style & ,708 & $>0,60$ & Valid \\
\hline $\mathrm{X} 3.4$ & $<-$ & Leadersip_style &, 746 & $>0,60$ & Valid \\
\hline $\mathrm{X} 3.5$ & $<-$ & Leadersip_Style &, 752 & $>0,60$ & Valid \\
\hline X3.6 & $<-\ldots$ & Leadersip_Style &, 756 & $>0,60$ & Valid \\
\hline
\end{tabular}

Results of Confirmatory Factor Analysis for exogenous constructs Table 2 above is used to test the unidimensionality of the latent constructing indicators aboveshowing loading factors of all the exogenous latent constructing indicators> 0.60 so the results of the measurement model are in accordance with the criteria specified in SEM so that the measurement model can proceed next step.

\section{Confirmatory Factor Analysis Construct} Endogen 


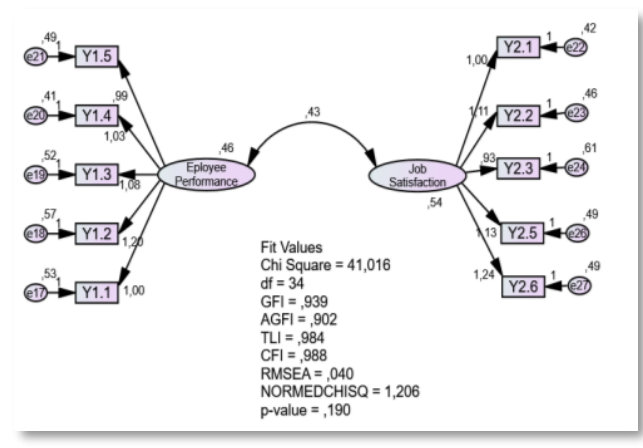

Figure : 3 CFA Construct Endogen

Table 2: Factor Loading CFA Kontruk Endogen

\begin{tabular}{|c|c|c|c|c|c|}
\hline \multicolumn{3}{|c|}{ Regression Weights } & \multirow{2}{*}{$\begin{array}{l}\text { Estimate } \\
, 685\end{array}$} & \multirow{2}{*}{$\frac{\text { Cut Off }}{>0,60}$} & \multirow{2}{*}{$\begin{array}{l}\text { Kesimpulan } \\
\text { Valid }\end{array}$} \\
\hline $\begin{array}{ll}\text { Y1.1 } \\
\end{array}$ & $<\ldots$ & Eployee_Performance & & & \\
\hline Y1.2 & $<-$. & Eployee_Performance &, 735 & $>0,60$ & Valid \\
\hline Y1.3 & $<\ldots$ & Eployee_Performance & ,715 & $>0,60$ & Valid \\
\hline Y1.4 & $<-$ & Eployee_Performance &, 740 & $>0,60$ & Valid \\
\hline Y1.5 & $<-$ & Eployee_Performance & ,694 & $>0,60$ & Valid \\
\hline Y2.1 & $<-$ & Job_Satisfaction &, 748 & $>0,60$ & Valid \\
\hline Y2.2 & $<\ldots$ & Job_Satisfaction &, 769 & $>0,60$ & Valid \\
\hline Y2.3 & $<-$ & Job_Satisfaction & ,658 & $>0,60$ & Valid \\
\hline Y2.5 & $<-$ & Job_Satisfaction &, 762 & $>0,60$ & Valid \\
\hline Y2.6 & $<-$ & Job_Satisfaction & ,791 & $>0,60$ & Valid \\
\hline
\end{tabular}

The results of the Confirmatory Factor Analysis for the endogenous contract of Figure 3 above are used to test the unidimensionality of the latent constructing indicator having a loading factor for all endogenous construct constructing indicators $>0.60$. The next stage can be continued, for structural analysis (Full SEM model), see Figure 4 below:

\section{Structural Equation Modeling (SEM) or Structural Modeling}

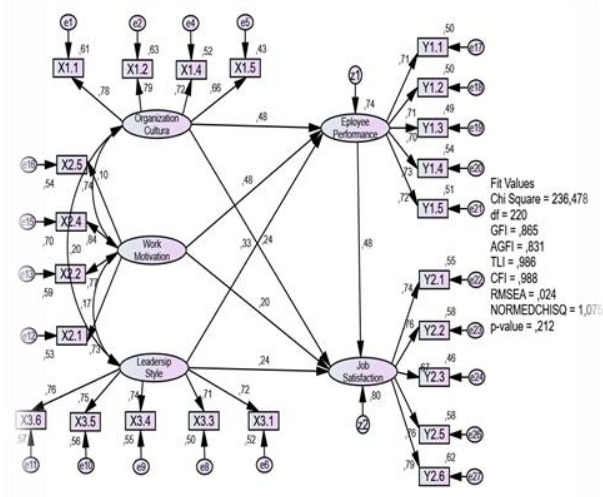

Figure: 4 Full Model Structural
The results of the Structural Model for the endogenous contract of Figure 4 above used to test the unidimensionality show the value of the model results in accordance with the Goodness of fit criteria so that the model can be accepted.

Table 3. GOF Indexes to Full Model

\begin{tabular}{|l|l|l|l|}
\hline Goodness of Fit Index & $\begin{array}{l}\text { Cut-off } \\
\text { Value }\end{array}$ & $\begin{array}{l}\text { Hasil Analisis } \\
\text { Model Structural }\end{array}$ & Evaluasi Model \\
\hline$\chi^{2}$ Chi-Square Statistik & df, $a=5 \%$ & 236.478 & Diharapkan Kecil \\
Probability & $\geq 0,05$ & 0.212 & Baik \\
CMIN/DF & $\leq 2.00$ & 1.075 & Baik \\
GFI & $\geq 0.90$ & 0.865 & Marginal \\
AGFI & 30.90 & 0.831 & Marginal \\
TLI & 30.95 & 0.986 & Baik \\
CFI & 30.95 & 0.988 & Baik \\
RMSEA & $\leq 0.08$ & 0,024 & Baik \\
& & & \\
\hline
\end{tabular}

The table 3 above shows that the suitability test of this model produces a good level of acceptance of the fit model so that it can be concluded that the resulting model can test the hypotheses that have been prepared and can answer all the above problem formulations.

\section{Discussion}

Based on the results of data analysis using a structural model (SEM) and to answer the hypotheses that have been prepared above, the results of this study will be reported with theory, expert opinion and previous research, namely:

Table 4: The Influence of Construct

Eksogen toward Construct Endogen

\begin{tabular}{|c|c|c|c|c|c|c|c|}
\hline Regression Weights & & & Est. & Est. Std. & S.E. & $C . R$ & $P$ \\
\hline Eployee Pefformance & $<\ldots$ & Organization_Cultura & 411 & .482 & .079 & 5,205 & 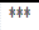 \\
\hline Eployee Pefformance & $<\ldots$ & Work Motivation & .426 & ,481 & .083 & 5,136 & *** \\
\hline Eployee_Pefformance & $<\ldots$ & Leadersip_Style &, 303 & .330 &, 078 & 3,878 & *** \\
\hline Job_Satisfaction & $<$. & Organization_Cultura & .207 & .235 &, 099 & 2,091 & 037 \\
\hline Job_Satisfaction & $<.$. & Eployee_Performance & ,494 &, 477 &, 185 & 2,675 & ,007 \\
\hline Job_Satisfaction & $<.$. & Work_Motivation & , 184 & 201 &, 101 & 1,828 & 067 \\
\hline Job_Satisfaction & $<\ldots$ & Leadersip_Style &, 230 &, 242 &, 088 & 2,629 &, 009 \\
\hline Eployee_Pefformance & $<$. & Organization_Culura & ,411 & ,482 &, 079 & 5,205 & *** \\
\hline Eployee_Pefformance & $<-$ & Work Motivation &, 426 & ,481 &, 083 & 5,136 & **** \\
\hline
\end{tabular}

Based on Table 5 above shows that the results of structural equation (SEM) have been analyzed according to the stages in SEM modeling, including Confirmatory Factor Analysis, Convergent Validity, Construc Reliability, Discriminant Validity and SEM assumptions that have met the requirements of structural models, so discussions and studies can be carried out from the results of the study as follows: 
1. The Influence of Organizational Culture toward Employees Performance

The results of this study have an influence between organizational culture and employee performance, so that opinion can strengthen the results of this study.

2. The Influence of motivation toward Employees Performance

The results of his research there is an influence between motivation with the work performance of employees, so that opinion can strengthen the results of this study.

3. The Influence of Leadership Style toward Employees Performance

The results of his research there is an influence between leadership style with employee performance, so that opinion can strengthen the results of this study.

4. The Influence of Organizational Culture toward Employees Performance

The results of his research there is an influence between organizational culture and job satisfaction, so that opinion can strengthen and support the results of this study.

5. The Influence of work motivation toward Employees Performance

The results of his research there is an influence between work motivation with job satisfaction, so the results of this study are not supported by the opinions of the experts above.

6. The Influence of Leadership Style toward Employees Performance

The results of his research there is an influence between leadership style with job satisfaction, so that opinion can strengthen and support the results of this study.

7. The Influence of Employees Performance toward Employees Performance satisfaction

The results of his research there is an influence between employee performance with job satisfaction, so that opinion can strengthen and support the results of this study.

\section{CONCLUSION}

Based on data analysis and discussion several things can be concluded as follows:

1. Organizational culture directly affects the performance of employees of PT. Bank BNI, the working area of Bank Indonesia Lhokseumawe.

2. Work motivation directly affects the performance of employees of PT. Bank BNI, the working area of Bank Indonesia Lhokseumawe.

3. Leadership style directly influences the performance of employees of PT. Bank BNI, the working area of Bank Indonesia Lhokseumawe.

4. Organizational culture directly affects the job satisfaction of employees of PT. Bank BNI, the working area of Bank Indonesia Lhokseumawe

5. Work motivation does not directly affect the job satisfaction of employees of PT. Bank BNI, the working area of Bank Indonesia Lhokseumawe.

6. Leadership style directly influences the job satisfaction of employees of PT. Bank BNI, the working area of Bank Indonesia Lhokseumawe.

7. Employee performance directly affects the job satisfaction of employees of PT. Bank BNI, the working area of Bank Indonesia Lhokseumawe.

\section{REFERENCES}

Bangun, Wilson. Manajemen Sumber Daya Manusia, Jakarta : Erlangga, 2012.

Bernadin, H. John and Joyce. A. Russell. Human Resource Management: An Experiential Approach, Boston: Mc.Graw Hill, 1993.

Baron, R. M., \& Kenny, D. A. The moderator-mediator variable distinction in social psychological research: Conceptual, strategic, and statistical considerations. Journal of Personality and Social Psychology, 51, 1173 1182. 1986

Brasmasari, Ida Ayu dan Suprayetno, Agus., "Pengaruh Motivasi Kerja, 
Kepemimpinan dan Budaya Organisasi Terhadap Kepuasan Kerja Karyawan Serta Dampaknyaada Kinerja Perusahaan." Studi kasus pada PT. Pei Hai International Witama Indonesia. Jurnal, Manajemen dan Kewirausahaan, Vol. 10. Nomor. 2, 2008.

Camaron, K.S, and Quin E. Robert. $3^{\text {th }}$ edition. Diagnosing and Changing Organizational Culture based on the competing value Framework Addison-Wesley, USA: Publishing Company, Inc, 2011.

Djati S.P dan Darmawan, Didit, Pengaruh Kinerja Karyawan Terhadap Kepuasan , Kepercayaan dan Kesetiaan Pelanggan, Jurnal Ekonomi Dan Manajemen Universitas Kristen Petra, Vo; 7 No. 1 Surabaya, 2005.

Ferdinand, Augusty, Metode Penelitian Manajen, Podoman Penelitian Skripsi, Tesis, dan Desertas Ilmu Manajemen, Edisi kelima, Semarang : BP-UNDIP,. 2014.

Ferdinand, Augusty. Structural Equation Modelin Dalam Penelitian Manajen, Edisi Kelima, BP-UNDIP, Semarang, 2014.

Ghozali, Imam,. Konsep dan Aplikasi Dengan Progran AMOS 22.0, Cetakan ke 6, Semarang : Badan Penerbit Universitas Diponegoro, 2014,

Ivancevich, John M, Konopaske dan Matteson. (2006). Perilaku Dan Manajemen Organisasi. Edisi 7 Jilid 2. Alih bahasa: Dharma Yuwono. Jakarta: Erlangga.

Khoirul, Muhammad., "Pengaruh Budaya Organisasi, terhadap Kinerja Pegawai Universitas Muhammadiyah Malang , Lembaga Penelitian Universitas Muhammadiyah, Malang, 2001.

Koesmono H. Teman., (2005). Pengaruh Budaya Organisasi Terhadap Motivasi dan Kepuasan Kerja Serta Kinerja Karyawan Pada
Sub Sektor Industri Pengelahan Kayu Ekspor di Jawa Timur, Desertasi Universitas Airlangga, Surabaya.

Lok, Peter and John Crawford., (2003). The Effect of Organizational Culture and Leadership Style on Job Satisfaction and Organizational Commitment, A-Cross-national comparison, Jornal of Management Development; 2004; 3/4; ABI/INFORM Research, Pg 321.

Lumbanraja, Prihatin., (2008). Desertasi: Pengaruh Kateristik Individu, Gaya Kepemimpinan dan Budaya Organisasi Terhadap Kepuasan Kerja dan Komitmen Organisasi, Program Pascasarjana, Universitas Brawijaya Malang.

Luthans, Fred., (2011). Organizational Behavior, Twelfth Edition, McGraw-Hill Companies Inc. New York.

Mangkunegara, A.A. Anwar Prabu., (2007). Evaluasi kinerja SDM, Rafika Aditama, Bandung.

Marbawi. Pengaruh Karakteristik Individu, Budaya Organisasi Dan Kepemimpinan Trasformational Terhadap Kepuasan Kerja Dan Kinerja Pada PT. Bank Aceh, Desertasi Universitas Sumatera Utara, Medan, 2018.

Mas'ud, Fuad., (2004). Survai Diagnosis Organisasiaonal : Konsep dan Aplikasi. Banan Penerbit Universitas Diponegoro, Semarang.

Milkovich, Geroge, T \& Boudreau, John, W., (1996). Human Resource Management, Irwin Homewood, Boston.

Munandar, A.S., Bertina Sjabaddhyni dan Rufus Patty Wutun., (2004). Peran Budaya Organisasi Dalam Peningkatam Unjuk Kerja Perusahaan, Depok. Penerbit PIO Fakultas Psikologi, Universitas Indonesia, Jakarta.

Ndraha, Taliziduhu., (2003). Budaya Organisasi, Cetakan Kedua, Penerbit Rineka Cipta, Jakarta. 
Nimran, Umar., (2004). Perilaku Organisasi, Cetakan ketiga, CV. Citra Media, Surabaya.

Noor, Juliansyah., (2013). "Penelitian Manajemen" Tinjauan Filosofis dan Praktis Edisi Pertama, Prenadamedia Group, Jakarta.

Rivai, Veithzal dan E.J. Sagala., (2011). Manajemen Sumber Daya Manusia untuk Perusahaan: dari Teori Ke Praktik, Edisi Pertama, Penerbit PT. Raja Grafindo Persada, Jakarta.

Robbins, Stephen $\mathrm{P}$ dan Timothy A. Judge., (2013). Organizational Behavior, Prentice Hall Inc., New Jersey.

Schein, Edgar H., (1992). Organizational Culture and Leadership, 2 nd JosseyBass Publisher, San Fransisco.

Sedarmayanti, (2007). Manajemen Sumber Daya Manusia: Reformasi Birokrasi dan Manajemen Pegawai Negeri Sipil, Cetakan Pertama, Penerbit PT.Refika Aditama, Bandung.

Siahaan, Elisabet., (2007). Anteseden Kinerja Karyawan dan Pengaruhnya Terhadap Kepuasan Kerja Karyawan: Studi Berdasarkan Perspektif Jender Pada Sektor Jasa Perbankan di Wilayah DKI Jakarta, Universitas Brawijaya Program Pascasarjana, Malang.

Siahaan, Elisabet., (2017). Antecedents Of Employee Performance And The Influence On Employee Job Satisfaction In Banking Service Sector In Indonesia, Bank and Bank Systems, Volume 12, Issue 4. LLC "CPC" Business Perfectives, Hryhorii Skovoroda Lanc, 10, Summy, 40022, Ukraine.

Sujak, Abi., (1990). Kepemimpinan Manager Eksistensi dalam Perilaku Organisasi. PT Gramedia, Jakarta.

Wibowo, (2010). Budaya Organisasi, Rajawali Pers, Jakarta. 